\title{
下咽頭癌に対する頸部食道再建後の唾液瘻 一術前照射量と発生頻度との関係からみた各種有茎弁法の選択基準一
}

\author{
慶応義塾大学医学部耳鼻咽喉科学教室（主任：斉藤成司教授） \\ 村上泰, 猪 狩武詔，原口茂徳，岡田康司，丸山 毅, \\ 館 野 秀 樹, 藤 村 昭 子, 浦尾弥須子, 中山 尚 樹
}

\section{SALIVARY FISTULA OF RECONSTRUCTED CERVICAL ESOPHAGUS IN HYPOPHARYNGEAL CANCER}

\author{
YASUSHI MURAKAMI, M. D., TAKETSUGU IKARI, M. D., SHIGENORI HARAGUCHI, M. D., \\ KOHJI OKADA, M. D., TAKESHI MARUYAMA, M. D., HIDEKI TATENO, M. D., \\ AKIKO FUJIMURA, M. D., YASUKO URAO, M. D. and NAOKI NAKAYAMA, M.D.
}

Department of Otolaryngology, School of Medicine, Keio University, Tokyo

In order to obtain a guide line for the best selection of the reconstructive technique of the cervical esophagus after total laryngopharyngectomy for hypopharyngeal cancer, the incidence of salivary fistula was investigated and statistically analyzed in every patient with different local condition that may be embellished mostly in response to the total dose of preoperative radiotherapy. The flaps investigated are DP, slit technique of DP, pectoralis major myocutaneous, skin grafted pectoralis major muscle and latissimus dorsi myocutaneous flaps.

As the result of statistical analysis, we conclude that the pectoralis major myocutaneous flap must be utilized as the first choice in patients without preoperative radiotherapy or irradiated by the total dose less than $46 \mathrm{~Gy}$, and that the slit technique of DP is much safer in patients irradiated more than $60 \mathrm{~Gy}$.

Key word：下咽頭癌，頸部食道再建，唾液㾇，有荎弁法，選択基準

A90-1042-53381

下咽頭頙部食道癌の治療において, 再建外科の占め る役割はきわめて大きい. 1968 年に Bakamjian"1)によ って開発された DP 皮弁法は，良い再建法のなかった 当時としては画期的な手術法であり, axial pattern flap という概念導入のきっかけともなって，わが国で も多くの症例に応用された ${ }^{2334)}$. しかしその欠点は, 二 期的であるために長期間を要することと，二次手術後 に食道吻合部の唾液瘦を生じ易く，そのためにさらに 長期間を費やす結果となることであった。 そこで，吻 合法に工夫がなされ，茎部の中央に縦切開を入れてそ
こへ食道断端を端々吻合するスリット法5)が開発され た.

一方, 二期的で長時間を要するという久点を解消す るために，胃や結腸などの腹部消化管を有茎性につり 上げる pull up operation ${ }^{6778)}$ が外科領域で広く行わ れると同時に，大胸筋皮弁910111 2 代表される筋皮弁 法が一期的手術法として開発された。 そして現在では, 有茎弁法としてこれら 3 つ再建法が多くの施設で用 いられており，主として形成外科領域で開発され進步 してきた遊離弁法を加えて, 必要に応じて適宜選択さ 
れるようになっている.

われわれは過去 20 年間に,これらすべての再建法を 利用して約 230 例の食道再建を経験したが，これらの うち食道全摘後の pull up operation を除く下咽頭頸 部食道再建は約 200 例で，その再建に主として用いた 方法は DP 皮弁法, DP 皮弁スリット法, 大胸筋皮弁 法, 植皮大胸筋弁法 ${ }^{12)}$, 広背筋皮弁法 ${ }^{13)}$ の 5 つの有茎 弁法であった。これらは，それぞれに長所と短所があ って，その特徴をよくわきまえたうえで選択して利用 しないと，長所を生かすことすらできなくなる．

下咽頭頸部食道再建において, 失敗の原因となる最 も厄介な合併症の一つに唾液㿉がある ${ }^{14}$. 多くは食道 端との吻合部に生じ，経口摄食を開始することができ ず，感染を伴って治瘜が遅れ，結果として吻合部狭窄

表 1 A 術前の全身的 High Risk一覧. このよ うな所見を示すものでは唾液漊の頻度が 高くなるため,対象から除外してある。

A. 術前の全身的 High Risk

1. 循環系異常

1) 不整脈, 高血圧, 浮腫, 心雑音.

2) 胸部 X 線異常 (肺浮腫など).

3 ) 心電図異常 (AVブロック, ST, T変化 など)。

2. 呼吸珙常

1) 肺疾患既往 (結核, 肺気腫, 気管支挔張 症など).

2) 肺活量 $2000 \mathrm{ml}$ 以下，\%V C 80\%以下，1 秒率 $70 \%$ 以下.

3 ) 血液ガス $\mathrm{PaO}_{2} 80 \mathrm{~mm} \mathrm{Hg}$ 以下, $\mathrm{PaCO}_{2} 50 \mathrm{~mm}$ Hg以上.

3. 竪機能異常

1) BUN $20 \mathrm{mg} \%$ 以上，クレアチニン $1.5 \mathrm{mg} \%$ 以上.

4. 肝機能異常

1) GOT, GPT 50以上.

5. 血液異常

1) 赤血球 300 万以下, ヘモグロビン $10 \mathrm{~g} / \mathrm{dl}$ 以下の貧血.

2) 総蛋白 $5 \mathrm{~g} / \mathrm{d} 1$ 以下, アルブミン $3 \mathrm{~g} / \mathrm{d} 1$ 以 下の低蛋白血症.

6 . 糖尿

1) $50 \mathrm{~g}$ 投与 OGTT で60分值 150 以上

2）ケトン尿 $(+)$.
を来すことが多く ${ }^{15)}$, 術後照射の開始が遅れて治療成 績悪化の原因ともなりうる.

われわれは再建食道における唾液瘦の成因について 検討し報告14115) してきたが，ここではその発生頻度と 発生症例につけて，各有茎弁法別に調査してみた。唾 液瘦を来す要因には全身的因子, 切除範囲, 再建手技, 術後管理など多くの因子が関与していると思われるの で，あらかじめこれらの因子を除外して対象を定める ことにより，局所条件，特に術前照射量と発生頻度と の関係を明らかにし，局所条件に応じた適応基準を得 ることを目的とした。

\section{1. 調查対象}

1986 年 8 月までの過去 20 年間にわれわれが治療し た下咽頭癌のうちで，咽喉頭頸部食道全摘出術（咽喉 食摘）を施行し，DP 皮弁法，DP 皮弁スリット法，大 胸筋皮弁法, 植皮大胸筋弁法拉よび広背筋弁法の 5 種 類の有萃弁法を用いて一次的再建手術を行った症例は 204 例であった。

これらのうちで, 再建手技または術後管理に明らか な原因（術中血管損傷，術後圧迫など）があって皮弁 壊死を生じたものが 9 例あり，これらは調查対象から 除外した．また，術前後の管理面で特に問題のあった 著しい全身異常所見（表 1) ${ }^{16)}$ を示していたもの 22 例, および極端な広範囲切除（緹廓郭清や中咽頭合併 切除）を施行したもの 10 例も調査対象から除外した。 これらの 41 例を除く 163 例を調查対象とした。

表 $1 \mathrm{~B}$ 術後の全身的異常所見. このような所 見を示したものでは唾液霬発生頻度が 高いため, 対象から除外してある。

B. 術後の全身異常所見

1. 呼吸循環異常

1) 心電図異常 (表 1 A と同様).

2) 血液ガス 酸素投与下で $\mathrm{PaO}_{2} 70 \mathrm{~mm} \mathrm{Hg}$ 以

下, 調節呼吸下, $5 \mathrm{cmH}_{2} \mathrm{O}$

PEEP 付加でも $70 \mathrm{~mm} \mathrm{Hg}$ 以下.

2、腎機能異常

1) 尿量 時間尿 $30 \mathrm{~m}$ 以下.

3. 肝機能異常 (表 1 A と同様).

4. 血液異常 (表 $1 \mathrm{~A}$ と同様).

5 . 糖尿

1) 尿糖 $(+) ， ケ ト ン$ 尿 $(+)$.

2) 標準栄養投与で血糖 $200 \mathrm{mg} / \mathrm{dl}$ 以上. 
再建手術の成否に関係が深い局所条件とされている 術前照射線量については，照射がなされていないもの が 30 例, 計画治療として $30 \mathrm{~Gy}$ 以下のもの, $46 \mathrm{~Gy}$ の ものがそれぞれ 52 例, 44 例であった。 また, $60 \mathrm{~Gy}$ 以 上のものが 37 例で,これらは早期癌に対する計画治療 後の再発症例, 初治療時手術拒否症例, 他院初治療症 例であった。

照射がなされていた症例のうちで特に好ましくない 局所条件とされている組織の hypovascular な線維化 については, 計画治療として術前照射された $30 \mathrm{~Gy}$ 以 下照射群抽よび $46 \mathrm{~Gy}$ 照射群では認められず, $60 \mathrm{~Gy}$ 以上照射群で照射終了後 6 力月以上を経過していた 27 例に認められた。

\section{2. 調查方法}

これらの 163 症例を再建法別に 5 群に分類して, 各々について唾液瘦の発生頻度を検索し,さらに術前 照射線量別に，非照射群，30 Gy 以下昭射群，46 Gy 照射群, $60 \mathrm{~Gy}$ 以上照射群に細別して検索し, 統計学 的に比較検討した。 $60 \mathrm{~Gy}$ 以上照射群でつよい線維化 を認めたものについては特に注意して検討した，有意 性の判定は $\mathrm{x}^{2}$ 検定によった.

\section{3. 結 果}

調查結果をまとめて表 2 に示す.

1) DP 皮弁法 (Bakamjian 原法)

DP 皮弁法を用いた再建はすべて 1979 年以前に行
われたものである．非照射群はなく，30 Gy 以下照射 群て 52 例, $46 \mathrm{~Gy}$ 照射群で 3 例, $60 \mathrm{~Gy}$ 以上照射群 で 16 例, 合計 71 例に行われている.

各群に扔ける唾液掼発生頻度は，それぞれ 35\%, $66 \% ， 88 \%$ で，30 Gy 以下照射群と $60 \mathrm{~Gy}$ 以上照射 群とで有意の差が認められた。 $60 \mathrm{~Gy}$ 以上照射群 16 例 のうちでつよい線維化を認めたものが 10 例あったが, そうでなかったものと比較して発生頻度に有意差はな く,ともに高頻度であった。総合すると 71 例中 34 例, 48\%に見られたことになり, 他の有茎弁法に比較して 有意に高頻度であった。

2）DP 皮弁スリット法

$\mathrm{DP}$ 皮弁スリット法による再建はすべて 1981 年以 後に行われたものである。すべて $60 \mathrm{~Gy}$ 以上照射群に 行われ, 合計 14 例で, そのうち線維化のつ上かったも のは 12 例であった.これらのうち線維化のつよかった もののわずか 1 例, $7 \%$ に唾液㾇を生じた.

3）大胸筋皮弁法

大胸筋皮弁法による再建はすべて 1980 年以後に行 われたものである.すでに治療計画が変更されていた ため, $30 \mathrm{~Gy}$ 以下群はなく, 非照射群て 25 例, $46 \mathrm{~Gy}$ 照射群で 35 例, $60 \mathrm{~Gy}$ 以上照射群で 7 例, 合計 67 例 に行われている.

各群に扔ける唾液瘦発生頻度は，それぞれ $8 \%, 9 \%$, $71 \%$ で, $60 \mathrm{~Gy}$ 以上照射群で有意に高頻度であった。 $60 \mathrm{~Gy}$ 以上照射群 7 例のうち線維化のつよかったもの が 5 例であったが，そうでなかったものと比較して有

表 2 術前照射線量による群別と各群における各有茎弁法の唾液瘦発生頻度

\begin{tabular}{|c|c|c|c|c|c|}
\hline & 非照射群 & $\begin{array}{c}\text { 30Gy以下 } \\
\text { 照射群 }\end{array}$ & $\begin{array}{l}46 \mathrm{~Gy} \\
\text { 照射群 }\end{array}$ & $\begin{array}{l}60 \mathrm{~Gy} \text { 以上 } \\
\text { 照射群 }\end{array}$ & $\begin{array}{c}\text { 計 } \\
(\mathrm{n}=163)\end{array}$ \\
\hline $\begin{array}{l}\text { D P 皮弁法 } \\
\text { (Bakamjian原法) }\end{array}$ & - & $\begin{array}{l}18 / 52 \\
=35 \%\end{array}$ & $\begin{array}{l}2 / 3 \\
\quad=66 \%\end{array}$ & $\begin{array}{l}14 / 16 \\
=88 \%\end{array}$ & $\begin{array}{l}34 / 71 \\
=48 \%\end{array}$ \\
\hline $\begin{array}{l}\text { D P 皮弁 } \\
\text { スリット法 }\end{array}$ & - & - & - & $\begin{array}{l}1 / 14 \\
\quad=7 \%\end{array}$ & $\begin{array}{l}1 / 14 \\
\quad=7 \%\end{array}$ \\
\hline 大胸筋皮弁法 & $\begin{array}{l}2 / 25 \\
\quad=8 \%\end{array}$ & - & $\begin{array}{l}3 / 35 \\
\quad=9 \%\end{array}$ & $\begin{array}{l}5 / 7 \\
=71 \%\end{array}$ & $\begin{array}{l}10 / 67 \\
=15 \%\end{array}$ \\
\hline 植皮大胸筋弁法 & - & - & $\begin{array}{l}2 / 5 \\
=40 \%\end{array}$ & - & $\begin{array}{l}2 / 5 \\
=40 \%\end{array}$ \\
\hline 広背筋弁法 & $\begin{array}{l}1 / 5 \\
\quad=25 \%\end{array}$ & - & $0 / 1$ & - & $\begin{array}{l}1 / 6 \\
=17 \%\end{array}$ \\
\hline 計 $(n=163)$ & $\begin{array}{l}3 / 30 \\
\quad=10 \%\end{array}$ & $\begin{array}{l}18 / 52 \\
=35 \%\end{array}$ & $\begin{array}{l}7 / 44 \\
\quad=16 \%\end{array}$ & \begin{aligned} 20 & \multicolumn{3}{l}{37} \\
& $=54 \%\end{aligned}$ & $\begin{array}{l}48 / 163 \\
=29 \%\end{array}$ \\
\hline
\end{tabular}


意差はなく，ともに高頻度であった。総合すると 67 例 中 10 例，15\%に見られたことになる。

4）植皮大胸筋弁法

植皮大胸筋弁法は乳房が大きく, 皮下脂肪織が厚く, 筋皮弁法を適用しえない女性症例に対して 1980 年以 後の 5 症例に行われ，すべて $46 \mathrm{~Gy}$ 照射群であった。 これらのうちの 2 例, $40 \%$ に唾液瘦が見られた。DP皮． 弁法と有意の差はなく，大胸筋皮弁法と比較すると有 意に高頻度であった。

5）広背筋皮弁法

広背筋皮弁法は著しい胸毛のために大胸筋皮弁法を 適用しえなかった $46 \mathrm{~Gy}$ 照射後の男性症例 1 例と，大 胸筋皮弁法を適用しえなかった女性症例で, 1983 年以 後, 計画治療として術前照射を行わなくなってからの 5 例，合計 6 例に行われている。

これらの 6 例のうち，女性症例の 1 例， $17 \%$ に唾液 瘦が見られ，大胸筋皮弁法と比較して有意の差はなか った.

\section{4. 考按}

下咽頭癌切除後の橮部食道再建に際して, 唾液瘦は 最も厄介な術後合併症のひとつである.治撚が遷延し， 経口摄食が不能で, 郝後照射も開始できず, 計画治療 に破綻を生じ, 結果として治療成績の低下を招く恐れ がある、唾液瘦の成因として多くの因子が挙げられ， 全身的要因, 局所条件, 切除範囲, 手術手技, 術後管 理などが関係している.

表 1 に示した全身的異常所見はいずれも手術に際し ての危険因子で，どの再建法によっても，より高頻度 に唾液癭が発生しうるとされている ${ }^{16)}$. 高度の貧血や 低蛋白では術創治痛が阻害され，糖尿でよく見られる 微少循環障害は皮弁生着に悪影響を及涩す決定的因子 であるとされている．また，全身所見に異常があって， 望ましい術後管理を行えなかったもの，たとえば，腎 機能障害のために抗生剤, 特にアミノグリコシド系薬 剤投与に制限のあったものや，糖尿や肝機能障害のた めの食餌制限により低蛋白血症を余儀なくされたもの などでは皮弁生着力や組織修復力が劣ると考えられ， さらに術創感染,特に緑膿菌感染の危険を伴い, microvenous thrombosis から皮弁部分壤死を生じて唾液瘦 が発生する頻度が高いと考えられる。そこで，局所条 件からみた再建法選択基準を得ることを目的とする今 回の調査では，これらに該当する症例を対象から除外 することにした.
対象とした 163 症例に対する切除術式はほ涩一定 で,全例に咽喉食摘と患側の頸部郭清がなされている. ただし, 1982 年以後の 61 症例では, 全例に反対側の内 顓静脈を保存する両側の頸部郭清がなされている。こ の両群では手術時間と輸血量に多少の差があるが, 手 術侵襲にはほとんど差がないと思われるため,すべて 対象とすることにした．また, これらの全症例で再建 手技朽よび抗生剂投与を含む街後管理の方法はほほ一 定であったから，この調査で得られた結果は局所条件 だけが関係しているとみてよい.

有茎弁法による頸部食道再建外科は, 1968 年の BakamjianによるDP 皮弁法の報告以来，その改良法で ある DP 皮弁スリット法の開発, 筋皮弁法の開発導入, 植皮筋弁法の開発など, めまぐるしく進歩しつつ変遷 してきたため, 本調查対象での再建法もその進歩に対 応しつつ,また, 経験から得られた知識を反映しつつ 選択されてきた。従って, 本調查はランダム形式によ るものではない. しかし, 他の因子を極力排除して比 較検討することによって, 局所条件, 特に術前照射線 量に対応した再建法選択基準が得られるように配慮し たつもりである。

DP 皮弁法は筋皮弁法が開発導入された 1980 年ま での約 10 年間, 全症例に適用されたが, 当時は計画治 療として $30 \mathrm{~Gy}$ 術前照射していたため，30 Gy 以下 群 52 例に用いられている．その $35 \%$ に唾液瘦が見ら れたが，大部分は第二次手術後，食道との吻合部に生 じたものである ${ }^{14)}$. その後, 切除標本の病理組織学的 検索結果 ${ }^{17)}$ に基づいて照射量を $46 \mathrm{~Gy}$ に変更し, sequential chemo radiotherapy を術前治療に導入し たが,その頃に行われた 3 例では $66 \%$ 之高頻度に唾液 瘦を生じている。 また， $60 \mathrm{~Gy}$ 以上照射群の 16 例では 14 例, $88 \%$ と高頻度に見られているが, 線維化が特に 著しいと思われた群とそうでない群との間には有意の 差を認めなかった。なお，1983 年からは術前照射を廃 止し，できる限り早期に手術しできる限り早期に術 後照射を開始する治療計画となったため, 二期的再建 法である DP 皮弁法を適用する機会がなく，非照射群 で経験はないが, 優れた一期的再建法が選択しうる 現在では Bakamjian 原法の適応はないといってよ w.

大胸筋皮弁法は 1980 年以降現在までの 7 年間に 67 症例に対して適用された. 1983 年までは $46 \mathrm{~Gy}$ 術前照 射，その後，術前昭射しない方針となったので，46 Gy 照射群の 35 例, 非照射群の 25 例に行われ，唾液瘼発 
生頻度は両群ほほ同様に $10 \%$ 以下であった.一期的に 完成し，早期に術後照射を開始する計画にも都合のよ い優れた再建法であるため，われわれは現在でもこれ を第一選択として繁用している.ただし，60 Gy 以上 照射群での唾液㿋発生頻度は線維化の程度と関係なく $71 \%$ と高率で，そのほとんどは食道との吻合部に見ら れ，自然閉鎖を期待しえても吻合部狭窄をのこす危険 が大きいことはすでに報告15)したとおりである.

そこで, $60 \mathrm{~Gy}$ 以上照射されている症例ではこれ以 上の照射は過量となって好ましくなく, 従って術後照 射の必要もないことから, 早期完成よりも確実な再建 が望ましいという理由で，ほ济同時期に導入された DP 皮弁スリット法を適用してみた。そ結果は極め て良く，以後このような症例に対してはもっぱらこれ を用いることとなった。現在まで 14 例に行われて, 唾 液㾇の見られたものはわずか 1 例，7\%にすぎなかっ た. 少なくとも第一期手術では再建部が閉鎖腔となら ないからその危険はなく，第二期手術後の管理を慎重 （局所の洗浄や適切な圧迫など）にすれば，唾液瘻発生 の危険を最小限にくい止められる，完成までに約 8 な いし 10 週を要することになるが, 唾液瘦を生じてその 閉鎖に長期間を浪費するよりはむしろ早くてすむし， また吻合部狭窄を牫さぬ利点がある。初めからそのよ うな治療計画を立てるのが安全で，今後も多量照射症 例に対してはDP 皮弁スリット法をより安全な再建法 として選択すべきであると考える。

このような多量照射症例で，すでに両側の DP 皮弁 が使用しあって, なお線維化と吻合部狭窄のために再 手術を余儀なくされたものに対して，遊離空腸移植術 を用いて成功した経験がある. 本論文の目的は有茎弁 法と遊離弁法とを比較することではないが, microvascular surgery の進歩に伴って, 遊離移植法の安全性は 著しく上昇した，しかし，栄養血管を一度切断してか ら吻合するよりも，つながったまま利用する方が手術 操作もより単純で，より安全確実であるのは当然であ ろうから, 頸部食道のように有茎弁法で容易に再建し えて, 合併症も少なく，機能上も問題がないのであれ ば，ことさら遊離移植法を選択する理由はない，たた゚ し，このような症例にこそ利用価值があるものと考え ている.

女性症例，特に乳房が大きく，皮下脂肪が厚いため に大胸筋皮弁法を利用できない症例での再建法の選択 には大いに問題がある．植皮大胸筋弁法は美容上は極 めて優れているが，最近では注とんど利用する機会が
なくなった，その理由は, 完成までに時間がかかる欠 点があり,なるべく早期に切除再建を行うという現在 の治療方針に合致しないことと，46 Gy 照射群で示さ れたように, 術前照射を行う治療方針とした場合には， 唾液瘦の発生頻度が $40 \%$ と高いためである.

この上うな症例にこそ広背筋皮弁法の適応があると する意見には賛成できない.なぜなら，胸壁の皮下脂 肪が厚い症例では広背筋を被う皮下脂肪もまた厚いた めに，ほとんどの場合利用できないからである，本調 查でも，男性症例の 1 例を加えてわずか 6 例に利用し えただけで，そのうちの1例，17\%に唾液㿔が見られ た.

乳房の下垂した高齢女性では大胸筋皮弁法を適用し うるので問題はないが，これ以外に利用できる一期的 有茎弁法はないことの方が多いから，空腸や前腕皮弁 などの遊離移植法を利用するか，あるいは治療計画を 変更して, 術前照射を行った上で DP 皮弁スリット法 を用いることになる.

照射線量から唾液㿉の発生頻度をみると，60 Gy 以 上照射群に比較して, 非照射群および $46 \mathrm{~Gy}$ 照射群で 有意に少なかったが, $30 \mathrm{~Gy}$ 以下昭射群では差がなか った.局所条件からみれば少なくて当然と思われるが, DP 皮弁法での成績不良が反映したものであった. 筋 皮弁法による一期的再建では，非照射群と $46 \mathrm{~Gy}$ 照射 群では差がなく,いずれも低頻度であったのに対して, $60 \mathrm{~Gy}$ 以上照射群では圧倒的に（もちろん有意に）高 頻度で，このような症例では筋皮弁法を用いない方が よいことが示された，DP 皮弁法ではさらに高頻度て あったのに対して，DP皮弁スリット法では極めて(有 意に）低頻度て，第一選択であることが示された。

$60 \mathrm{~Gy}$ 以上照射群では, 照射終了後すでに 6 力月以 上経過していて線維化のつよいものがほとんどであっ たが，照射直後のものとの間に唾液瘦発生頻度の有意 差は認められず，いずれも著しく高頻度であった，照 射による hypovascular な線維化は終了後ある期間を 経過してから生じるものて，終了直後にはみられない にもかかわらず, 高頻度に睡液瘦がみられたことは臨 床上興味深い結果であった。

\section{5. 結 論}

下咽頭癌に対する咽喉食摘後の頸部食道再建におけ る最もポピュラーな合併症である唾液瘦について,DP 皮弁法, DP 皮弁スリット法, 大胸筋皮弁法, 植皮大胸 筋弁法および広背筋皮弁法の 5 種類の有茎弁法での発 
生頻度を統計学的に比較検討し, 特に術前照射線量と の関係を明らかにすることによって，局所条件に応じ た適応基準を得ることを試みた. その結果として以下 のように結論する。

1）DP 皮弁法での唾液㾇発生頻度は，他のどの有荎 弁法よりも高率で, 術前照射線量の多い群ほど高率で あった。

2）DP 皮弁スリット法は全て $60 \mathrm{~Gy}$ 以上照射群に対 して用いられたにもかかわらず，喠液㾇発生頻度は最 も低率であった。

3）大胸筋皮弁法を非照射群および $46 \mathrm{~Gy}$ 照射群に 対して用いた場合の睡液瘦発生頻度は低率であった が, 60 Gy 以上照射群では, DP 皮弁スリット法に比 較して有意に高頻度であった。

4）植皮大胸筋弁法は 46 Gy 照射後の女性症例にの み用いられたが, その唾液㾇発生頻度は大胸筋皮弁法 に比較して有意に高頻度であった。

5）広背筋皮弁法を利用しえた症例は少なかったが, その唾液實発生頻度は大胸筋皮弁法に比較して有意差 はなかった。

6）以上の結果からみて，非照射または $46 \mathrm{~Gy}$ 以下照 射群では，早期に術後照射を開始しうることが必要条 件となるため，一期的再建法で手技の容易な大胸筋皮 弁法を第一選択とすべきであるのに対して，すでに 60 Gy 以上照射してあって術後照射を行わない症例では DP 皮弁スリット法によるのが最も安全である。

\section{参 考 文 献}

1) Bakamjian VY : A two stage method for pharyngo-esophageal reconstruction with a primary pectoral skin flap. Plast Reconstr Surg $36: 173^{-}$ 184, 1968.

2）松浦秀博 他: Deltopectoral skin flap による頸部 食道再建の経験。日外会誌 $71 ： 934-941 ， 1970$.

3）村上 泰：下咽頭頸部食道の再建手術法とその選 択. 日医総会誌：953-968，1975.

4）村上 泰: DP 皮弁法の基礎知識と臨床応用. 耳鼻
臨床 69：481-487, 1976.

5）宔田哲昭 他：(16ミリ映画) DP 皮弁法による頸部 食道再建に扔ける吻合法の一工夫. 第 2 回日本頭頸 部腫瘍学会 : 1978.

6) Ong GB, Lee TL : Pharyngo-gastric anastomosis after esophagopharyngectomy for carcinoma of the hypopharynx and cervical esophagus. Brit J Surg $48: 193-202,1960$.

7）掛川暉夫 他：澒部食道癌の手術術式の検討. 日外 会誌 $71 ： 917-921,1970$.

8）秋山 博：非開胸食道摘出による一期的咽頭胃吻合 術. 手術 $27: 1-5,1973$.

9）村上 泰 他：大胸筋 myocutaneous island flap による頙部食道一期的再建術. 日気食会報 $31: 228$ $-237,1980$.

10）村上 泰: 大胸筋皮弁. 耳鼻展望 $23: 623-631$, 1980.

11）村上 泰：有荃筋皮弁による頸部食道再建術. 外科 mook Suppl 1:1-11, 1982 .

12) Murakami $Y$, Saito $S:$ Esophageal reconstruction with a skin grafted pectoralis major muscle flap. Arch Otolaryngol $108: 719-722,1982$.

13) Quillen CG : Latissimus dorsi myocutaneous flaps in head and neck reconstruction. Plast Reconstr Surg $63: 664-670,1979$.

14）村上 泰: DP 皮弁再建食道における食道皮成瘦； その成因と閉鎖手術.日気食会報 $28: 34-38,1977$.

15）猪狩武詔 他：大胸筋皮弁再建食道の吻合部狭窄の 成因とその対策. 日気食会報 $35: 34-39 ， 1984$.

16）村上 泰：頸部広範围切除術の術前術後管理. 日本 外科学会教育委員会編：臟器大量切除の術前, 術後 管理. 中外医学社，東京，1983，1-32 頁.

17）村上 泰 他：下咽頭頸部食道癌治療の進歩一切除 手術と再建手術一, 日気食会報 $34: 130-134,1983$ 。

(原稿受付 昭和 61.8 .27 日)

別刷請求先 $\overline{7} 160$ 東京都新宿区信濃町 35

慶応義塾大学医学部耳鼻咽诶科学教室 村上 泰 